masculine KA- of class IA '. It is usually said to be equivalent to 'mother of'. Namirembe, ' a very well known place of sanctuary in old Buganda in which a fugitive could not be molested ', would be literally ' the mother of peace'; Natete, 'mother of (place of) etete grass'; Nalubale, 'mother of the great spirit', is the name of Lake Victoria. The masculine prefix SE- corresponding to NA- might be rendered 'father of'; Seguku, 'the father of logs', is the name of a hill in Buganda on which grow massive trees which could not be carried away. Both these prefixes are found in personal names and also in place-names in other African countries. The locative A- or PA- takes the form of WA- in Ganda and occurs, says Mr. Snoxall, in the majority of truly descriptive geographical names, e.g. Wandegeya, 'the place of weaver birds'. The locative MU- ' is far from common 'in place-names; only one example is given, viz. Munsa, 'within the ditch'.

The prefix $\mathrm{KA}$ - is of particular interest. We have spent an idle hour in counting the names beginning with $\mathrm{Ka}$ in the index of The Times atlas so far as they are African-they number 260 and in all probability there are hundreds not recorded. They are found chiefly over a wide belt along the central axis running from Bechuanaland on the south to the AngloEgyptian Sudan, and also to a less extent in Nigeria, Dahomey, Ivory Coast, Liberia, Sierra Leone, and Senegal. What is the meaning of $\mathrm{KA}$ - in this context? Undoubtedly in many instances it is diminutive. Mr. Snoxall suggests that Kampala was originally $A$ kasozi ka-mpala, 'the little hill of the mpala antelope'. Kabira would be 'the nice little forest '; Kalungu, ' the little desert '. But, as Mr. Snoxall says, it is often difficult to see where the idea of smallness comes in. KA- has many other meanings. It is sometimes an honorific prefix as in Kabaka, Katekiro, the titles of the king and prime minister of Buganda; and it may be that many of the place-names are in reality titles or personal names; for example, Kazembe, which figures on the map as the name of a place in Northern Rhodesia, is properly the title of the chiefs whose capital that place was and is. $\mathrm{KA}$ - in some languages such as Zulu and Ila is a possessive particle used with personal names; thus in Zulu, Ka-Dinizulu means '(son) of Dinizulu'; and in Ila, isoko dya-ka-Shimunenga means 'the sacred grove of Shimunenga'. It is conceivable that some place-names have been formed by ellipsis, munzhi wa-ka-Mpanda, 'village of Mpanda', becoming Kampanda. KA- in many Bantu languages is a tense-particle, denoting past or future, and also imperative; and possibly some place-names may be sentences or the residue of proverbial phrases; e.g. Kamukamba might be a command to clap ( $k a m b a)$ the hands in sign of greeting or homage, and applied to a place where lived a great chief who had to be honoured in that manner. Mr. Snoxall suggests that KA- is often 'descriptive of a good place in which to find things', with no implication of smallness. 'The adjective 'good' would hardly apply to such a locality as Kakubansiri 'a place for mosquitoes'. It has been noted that in some languages $\mathrm{KA}$ - is a feminine or 'mother' prefix conveying the idea of bringing forth, producing, affording abundance of; and it is possible that the majority of place-names with that prefix carry such a suggestion. Mr. Snoxall instances Kabubbu, ' a good place for finding mbubbu grass '; Kamuli, 'a good place for reeds'; Kalisizo, 'a good place for pasture'. Thus outside Buganda: Kasenga, 'a place of sand'; Kabulwebulwe, 'a place of many iguanas'. What $\mathrm{KA}$ - means in Sudanic languages we do not profess to know. We should like to hear from readers who have made a study of African place-names.

\title{
Conference of Missionary Societies
}

Professor Daryll Forde, Director of the Institute, opened the session on 'The Gospel and Primitive Peoples' at the annual general meeting of the Conference of Missionary Societies of Great Britain and Ireland in June 1947. He indicated some of the difficulties which meet the administrator, the mercantilist, and the missionary called to work among 
so-called primitive peoples in small-scale societies. He pointed out that Christianity developed in a complex and advanced civilization and formulated ideas concerning man and the universe which people living within a narrow social orbit cannot readily grasp-for example, the Christian conception of the importance of the individual is often in discordance with ideas entrenched in the minds of primitive peoples. Furthermore, the traditional symbols which arouse socially and morally valuable responses among primitive peoples are derived from cultures and environments very different from those of the western world, which may have very little evocative power for members of less advanced societies. Harm can be done to the solidarity of a society by thoughtlessly or ignorantly destroying old values. For the Church, the problem arises of understanding the nature and the cultural background of native ideas and of expressing the values of Christianity in ways meaningful to such peoples. When members of primitive societies are subjected to the influences of western civilization and removed from the context of the old community life there is danger that intense individualism may replace a sense of responsibility and old accepted patterns of behaviour may be discredited. There is great need for Mission work to base itself on sound knowledge, otherwise the Church itself may unwittingly contribute to the disruptive process.

\section{Director's Visit to France and Belgium}

In September 1947 Professor Forde, Director of the Institute, spent some days in Brussels and Paris in consultation with the Belgian and French Directors. In Brussels he discussed with Professor de Jonghe arrangements for the collaboration of Belgian linguists in the Handbook of African Languages, with special reference to a study on the languages of the Belgian Congo, which could be included in the scheme of the Handbook and for which preliminary surveys were already in preparation. He also discussed with Professor De Jonghe and officials of the Belgian Ministère des Colonies proposals for a linguistic survey of the northern Bantu border area. Plans for this project, which the Institute hopes to carry out with the assistance of a team of British, French, and Belgian linguists, have been under discussion for some months, and it is now hoped that the project will receive favourable consideration from the Belgian authorities.

Professor Forde was able to inspect ethnographic material which is being assembled under the direction of the Commission of Ethnology at the Institut Royal Colonial Belge, and to consider means by which the work of the Commission might be related to the Institute's Ethnographic Survey project, and how the Institute might assist the Commission.

In Paris, Professor Forde had further discussions with Professor Griaule, the Institute's French Director, on the northern Bantu Survey project. Approaches already made to the French Government by Monsieur Charton had elicited a favourable response, and Professor Griaule undertook to submit further proposals in conjunction with Monsieur Charton. Arrangements for the prosecution of the Ethnographic Survey in French territories, with the collaboration of IFAN, were also considered.

While in Paris, Professor Forde was invited, as Director of the International African Institute, to attend a Conference on Philosophy and the Humanities held under the auspices of U.N.E.S.C.O. The Conference, under the Chairmanship of Professor Madariaga, was concerned with teaching and research in Philosophy and the Humanities as a means of furthering international understanding. Professor Griaule presented the case for the promotion of research and the dissemination of knowledge on indigenous African thought and social institutions. Professor Forde was given an opportunity to make the work and aims of the International African Institute known to the appropriate divisions of U.N.E.S.C.O. A resolution was formulated for submission to the general U.N.E.S.C.O. conference in 